\title{
Efficiency of a new Waitea circinata extract against rice pathogens ${ }^{1}$
}

\author{
Jacqueline Campos Borba de Carvalho ${ }^{2}$, Amanda Abdallah Chaibub ${ }^{2}$, Kellen Cristhina Inácio Sousa ${ }^{2}$, \\ Denise Candini de Brito ${ }^{2}$, Marta Cristina Corsi de Filippi ${ }^{3}$, Lucília Kato ${ }^{4}$, Leila Garcês de Araújo ${ }^{2}$
}

\section{ABSTRACT}

Waitea circinata (Warcup \& Talbot) is an orchid antagonist mycorrhizal fungus with biocontrol potential against rice pathogens. This study aimed to optimize the extraction method, obtain a new extract and evaluate its efficiency against rice pathogens in vitro and in vivo, as well as to compare it with other extraction methods and $W$. circinata. The extracts were obtained and screened for in vitro growth inhibition against the pathogens Cochliobolus miyabeanus, Monographella albescens and Sarocladium oryzae, using the following extracts: mycelial, crude, lyophilized and mycelial mass. An additional in vitro assay was performed with the principal rice pathogen (Magnaporthe oryzae), in order to evaluate the conidial germination and appressorium formation. Based on this evaluation, the lyophilized and mycelial mass extracts were tested in vivo against rice blast (M. oryzae) and compared to the $W$. circinata mycelial suspension, in different application forms (simultaneous and previous). The mycelial mass extract inhibited all the pathogens, and the crude and lyophilized extracts inhibited C. miyabeanus and M. albescens, respectively. The mycelial mass extract inhibited the $M$. oryzae conidial germination and appressorium formation by $80 \%$, and the simultaneous and previous applications suppressed the rice blast by $94 \%$. These results indicate that the new extract can be used to control rice pathogens.

KEYWORDS: Biocontrol, leaf scald, brown spot, sheath rot, rice blast.

\section{INTRODUCTION}

Brown spot (Cochliobolus miyabeanus), leaf scald (Monographella albescens), sheath rot (Sarocladium oryzae) and rice blast (Magnaporthe oryzae) affect the yield in upland and irrigated rice

\section{RESUMO}

Eficiência de um novo extrato de Waitea circinata contra patógenos de arroz

Waitea circinata (Warcup \& Talbot) é um fungo antagonista micorrízico de orquídea, com potencial de biocontrole contra patógenos de arroz. Objetivou-se otimizar o método de extração, obter um novo extrato e avaliar sua eficiência contra patógenos de arroz in vitro e in vivo, bem como compará-lo com outros métodos de extração e $W$. circinata. Os extratos foram obtidos e testados para inibição de crescimento in vitro contra os patógenos Cochliobolus miyabeanus, Monographella albescens e Sarocladium oryzae, utilizando-se os seguintes extratos: micelial, bruto, liofilizado e de massa micelial. Um ensaio adicional in vitro foi realizado com o principal patógeno do arroz (Magnaporthe oryzae), para avaliar a germinação de conídios e a formação de apressórios. Com base nessa avaliação, os extratos liofilizado e de massa micelial foram testados in vivo contra a brusone do arroz (M. oryzae) e comparados com a suspensão micelial de $W$. circinata, em diferentes formas de aplicação (simultânea e prévia). O extrato de massa micelial inibiu todos os patógenos, e os extratos bruto e liofilizado inibiram C. miyabeanus e $M$. albescens, respectivamente. O extrato de massa micelial inibiu a germinação de conídios e a formação de apressórios de $M$. oryzae em 80 \%, e as aplicações simultâneas e prévias suprimiram a brusone em $94 \%$. Os resultados indicam que o novo extrato pode ser usado para controlar patógenos de arroz.

PALAVRAS-CHAVE: Biocontrole, escaldadura, mancha parda, podridão da bainha, brusone.

(Fisher et al. 2012, Laha et al. 2017). The recorded losses in grain yield are $100 \%$ (rice blast), $90 \%$ (brown spot), $30 \%$ (leaf scald) and $90 \%$ (sheath rot) (Ou 1985, Rao 1996, Prabhu et al. 2009, Sunder et al. 2014). Although the disease management integrates genetic resistance, cultural practices and chemical

${ }^{1}$ Received: Dec. 07, 2020. Accepted: Mar. 15, 2021. Published: Apr. 30, 2021. DOI: 10.1590/1983-40632021v5166916.

${ }^{2}$ Universidade Federal de Goiás, Instituto de Ciências Biológicas, Departamento de Genética, Goiânia, GO, Brasil.

E-mail/ORCID: jacquelinecamposcarvalho@gmail.com/0000-0001-5393-9087; amandachaibub@gmail.com/ 0000-0002-4025-668X; bio.kcisbr@gmail.com/0000-0002-5512-855X; denisecandine@gmail.com/0000-0001-8780-4834; leilagarcesaraujo@gmail.com/0000-0002-3238-4999.

${ }^{3}$ Empresa Brasileira de Pesquisa Agropecuária (Embrapa Arroz e Feijão), Santo Antônio de Goiás, GO, Brasil. E-mail/ORCID: cristina.filippi@embrapa.br/0000-0003-1676-8164.

${ }^{4}$ Universidade Federal de Goiás, Instituto de Química, Goiânia, GO, Brasil.E-mail/ORCID: lucilia@ufg.br/0000-0003-1366-0764. 
control, fungicides are widely applied. In Brazil, the pesticide consumption reached 549,280 tons in 2018 (Ibama 2018), but the excessive use of fungicides causes environmental pollution, resistance of the pathogen to molecules, decrease in the number of non-target organisms, poisoning and cancer (Bozdogan 2014, Nascimento et al. 2020), being very important the search for disease control alternatives that are sustainable.

A great effort has been made to use bioagents in the field that are safe for consumers and for the environment, as well as more efficient than the existing ones and independent of the variability of pathogens (Oliveira et al. 2019, Chaibub et al. 2020). However, the efficacy of biological control agents may be affected by preparations formed with spore suspensions, mycelial cultures with media, pellet or powder/granular and extract formulations (Narayanasamy 2013, Carvalho et al. 2015).

Extracts are a set of molecules obtained from plants or microorganisms, and fungal metabolites are widely known to exhibit a broad range of biological properties, including antimicrobial activity (Synytsya et al. 2017).

Mycorrhizal fungi interact with hosts forming spiral complexes of fungal hyphae, called pelotons, which form during the symbiotic interaction with many orchid species (Rasmussen \& Rasmussen 2009, Sousa et al. 2019, Yeh et al. 2019). The orchid mycorrhizal fungi Waitea circinata is obtained from roots of the Brazilian Savanna orchid Epidendrum nocturnum. It is a non-obligate symbiont that acts as a biocontrol agent against plant pathogens (MosqueraEspinosa et al. 2013, Carvalho et al. 2015), being an option for the formulation of bioproducts.

$W$. circinata inhibits in vitro $M$. oryzae and its crude extract suppresses in vivo rice blast (Carvalho et al. 2015). However, the process is not adequate, because it takes 26 days, and a large amount of solvent is required (Carvalho et al. 2015). Thus, it is necessary to explore a reasonable extraction method.

There is no registered or recommended biological product from orchid mycorrhizal fungi or extracts to control these diseases (Agrofit 2021). The advantages of obtaining a bioproduct in the extract or isolated metabolite is the lack of need for cooling and a probable increase in shelf life due to a greater stability (Carvalho et al. 2015). Therefore, this study aimed to optimize the extract method, obtain a new extract and evaluate its efficiency against rice pathogens in vitro and in vivo, as well as to compare it with other extraction methods and $W$. circinata.

\section{MATERIAL AND METHODS}

The $W$. circinata was obtained from rupicolous E. nocturnum orchid from the Brazilian Savanna (Sousa et al. 2019) and belongs to the Microorganisms Genetics Laboratory of the Universidade Federal de Goiás (Goiânia, Goiás state, Brazil). The rice pathogen isolates (Cochliobolus miyabeanus - BRM 45114, Monographella albescens - BRM 32184, Sarocladium oryzae - BRM 6461 and Magnaporthe oryzae - BRM 31295) belong to the Multifunctional Collection of Microorganisms of the Empresa Brasileira de Pesquisa Agropecuária (Embrapa Arroz e Feijão). The assays were performed from May 2014 to July 2016.

The methodology applied to obtain the mycelial, crude and lyophilized extracts has been previously described by Carvalho et al. (2015).

The mycelial mass extract was obtained from $W$. circinata cultivation in PDA for 11 days, under continuous light, at $26 \pm 2{ }^{\circ} \mathrm{C}$. The mycelium was scraped with a scalpel to remove the excess of culture medium and $16 \mathrm{~g}$ of the mycelium were thawed, placed in flasks and macerated with $100 \mathrm{~mL}$ of ethyl acetate for cold extraction for 3 days. Filtration was then performed to remove the solid part using a Whatman $n^{\circ} 4$ filter paper under vacuum, and the solvent was removed on a rotary evaporator under reduced pressure for $1 \mathrm{~h}$. These procedures were repeated three times to obtain the mycelial mass extract (Figure 1).

The inhibition assays were performed using a completely randomized design, with six treatments and five replications for each pathogen. The microorganisms were grown in PDA for 11 days at $25^{\circ} \mathrm{C}$. Five dilutions of each extract were prepared. First, the samples were weighed and diluted in $2 \mathrm{~mL}$ of ethanol. Next, Milli-Q ${ }^{\mathrm{TM}}$ water was added to obtain the final concentration. The samples were then filtered through a syringe fitted with a Macherey-Nagel polytetrafluoroethylene membrane $(20 \mu \mathrm{m})$.

Extracts $(1 \mathrm{~mL})$ at each concentration were mixed with $15 \mathrm{~mL}$ of PDA in Petri dishes and stirred, so the extract mixed with the culture medium. After solidification, one disc of pathogen $(5 \mathrm{~mm})$ was transferred to the centre of each Petri dish and incubated at $27^{\circ} \mathrm{C}$, for 15 days, under continuous 


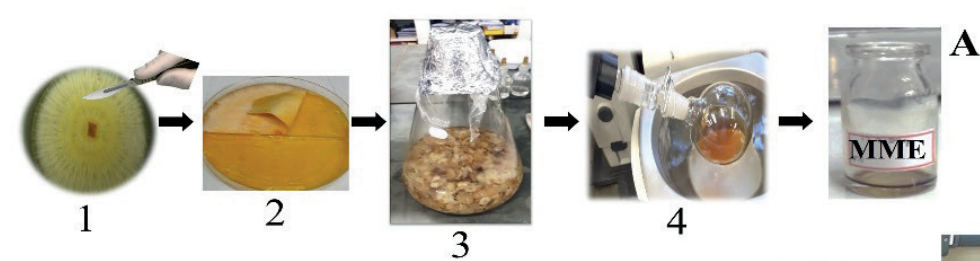

A

3

4

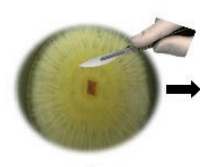

1

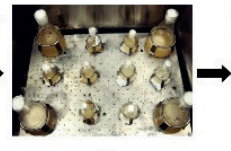

2

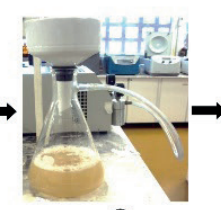

3

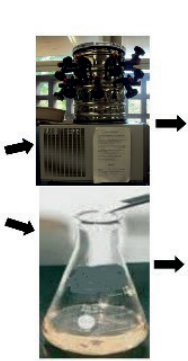

5

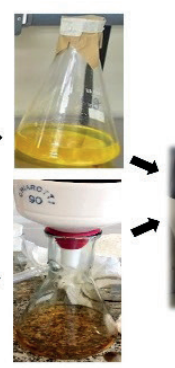

6

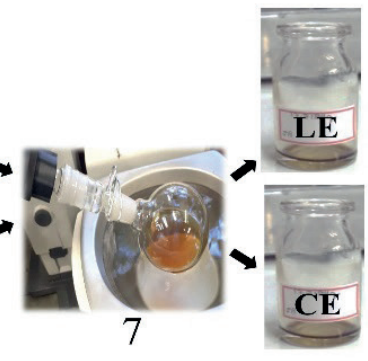

E

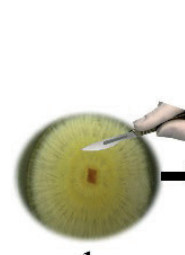

1

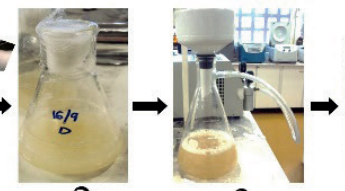

3

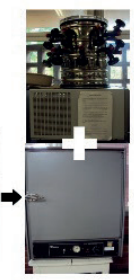

5

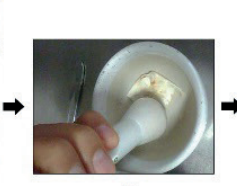

6

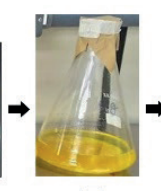

7

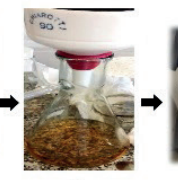

8

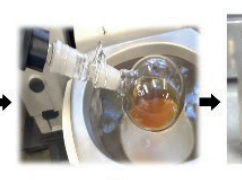

9

Figure 1. Steps for obtaining the $W$. circinata extracts. A) Mycelial mass extract (MME): 1 - PDA for 11 days; 2 - scraped mycelia; 3 - ethyl acetate for $72 \mathrm{~h} ; 4$ - solvent elimination in rotary evaporator. B) Lyophilized extract (LE): 1 - PDA for 11 days; 2 - 25 dishes on PD for 15 days; 3 - vacuum filter; 4 - liquid-liquid partition with ethyl acetate (aqueous fraction); 5 - lyophilization for $24 \mathrm{~h} ; 6$ - ethyl acetate; 7 - solvent elimination in rotary evaporator. Crude extract (CE): 1 - PDA for 11 days; 2 - 25 dishes on PD for 15 days; 3 - vacuum filter; 4 - liquid-liquid partition with ethyl acetate (organic fraction); 5 - anhydrous sodium sulphate; 6 - ethyl acetate and vacuum filtration in Buchner apparatus; 7 - solvent elimination in rotary evaporator. C) Mycelial extract (ME): 1 - PDA for 11 days; 2 - 25 dishes on PD for 15 days; 3 - vacuum filtration; 4 - mycelial mass; 5 - lyophilization $24 \mathrm{~h}+$ oven $24 \mathrm{~h} ; 6$ - ground mycelial; 7 - ethyl acetate for $48 \mathrm{~h} ; 8$ - vacuum filtration; 9 - solvent elimination in rotary evaporator.

light. The treatments consisted of $1,040 \mu \mathrm{g} \mathrm{mL}^{-1}$, $700 \mu \mathrm{g} \mathrm{mL}^{-1}, 520 \mu \mathrm{g} \mathrm{mL}^{-1}, 120 \mu \mathrm{g} \mathrm{mL}^{-1}$ and $12 \mu \mathrm{g} \mathrm{mL} \mathrm{m}^{-1}$ of extract, plus controls consisting of discs for each pathogen lacking extract.

The evaluations of the assays were performed when the control colony reached the edge of the dish. The horizontal and vertical diameters of pathogens were measured with a digital pachymeter to determine the colony area, and the reductions were calculated according to Carvalho et al. (2015).

To evaluate the effect of the mycelial mass extract on the conidial germination and appressorium formation, a $M$. oryzae isolate was grown and adjusted to $1 \times 10^{5}$ conidia $\mathrm{mL}^{-1}$ (Filippi \& Prabhu 2001). An aliquot of $10 \mu \mathrm{L}$ of $M$. oryzae suspensions and the mycelial mass extract (totalling $20 \mu \mathrm{L}$ ) were induced on a hydrophobic artificial surface previously sterilized under slides and kept under high humidity conditions at $27^{\circ} \mathrm{C}$, for evaluations after 3,6 and $24 \mathrm{~h}$. The slides were observed under a light microscope and the percentage of conidial germination and appressoria formation was determined by analysing 100 conidia per replicate. The assay was conducted in a completely randomized design, with six treatments and three replicates. The treatments consisted of five mycelial mass extract concentrations $(1,040 ; 700$; $520 ; 120$; and $12 \mu \mathrm{g} \mathrm{mL}^{-1}$ ) and the control (M. oryzae without mycelial mass extract).

The leaf blast suppression by $W$. circinata mycelial mass extract was performed with two applications methods: simultaneous and previous. For the simultaneous application, rice seeds of the BRS Primavera cultivar were sown in plastic tray grooves with $3 \mathrm{~kg}$ of soil fertilized with NPK (5 $\mathrm{g}$ of 5-30-15 + $\mathrm{Zn})$. Top dressing fertilization was performed at 18 days after sowing, using $3 \mathrm{~g}$ of ammonium sulphate per tray. The $M$. oryzae conidia production and inoculation $\left(3 \times 10^{5}\right.$ conidia $\left.\mathrm{mL}^{-1}\right)$ were performed according to Filippi \& Prabhu (2001).

Three assays were conducted in a completely randomized design, with three replications, under greenhouse conditions. Each treatment was sprayed 
simultaneously with $M$. oryzae $\left(3 \times 10^{5}\right.$ conidia $\left.\mathrm{mL}^{-1}\right)$ on 21-day-old rice plants (V3 stage). After growing on PDA, the $W$. circinata mycelia was scraped, weighed and diluted in autoclaved distilled water to obtain three suspensions at concentrations of 2; 5 ; and $10 \mathrm{~g} \mathrm{~L}^{-1}$.

In the first assay, the mycelial mass and crude extracts were compared for leaf blast severity suppression. The assay was performed with three treatments each, as it follows: crude extract at $1,040 \mu \mathrm{g} \mathrm{mL}^{-1}$, mycelial mass extract at $1,040 \mu \mathrm{g} \mathrm{mL}^{-1}$ and control. The second assay compared $W$. circinata extracts (mycelial mass and crude extracts) with mycelial suspensions for leaf blast severity, with six treatments, as it follows: mycelial suspensions at 2; $;$; and $10 \mathrm{~g} \mathrm{~L}^{-1}$, crude extract at $1,040 \mu \mathrm{g} \mathrm{mL}^{-1}$, mycelial mass extract at $1,040 \mu \mathrm{g} \mathrm{mL}^{-1}$ and control. The third assay compared the optimal treatments of the second assay with the following treatments: mycelial suspensions at $5 \mathrm{~g} \mathrm{~L}^{-1}$, crude extract at $1,040 \mu \mathrm{g} \mathrm{mL}^{-1}$, mycelial mass extract at $1,040 \mu \mathrm{g} \mathrm{mL}^{-1}$ and control.

Leaf blast severity (\%) was evaluated using a 10-grade rating scale (Notteghem 1981), at 8 days after the $M$. oryzae inoculation. For the first and third assays, the leaf blast severity was evaluated at 2-day intervals, to determine the area under the disease progress curve (AUDPC) (Shaner \& Finney 1977). The reduction in the rice leaf blast severity was calculated according to the severity in the inoculated control (Chaibub et al. 2019).

For the previous method, the planting, inoculation and evaluation were performed according to the simultaneous application assay, but the $W$. circinata applications were performed several days after planting (DAP). Planting was carried out on October 10, 2017. The assay was conducted with 10 treatments, as it follows: 1 - soil (soil mixed with $5 \mathrm{~g} \mathrm{~kg}^{-1}$ of fungal disc before planting); 2 - mycelial suspension $\left(5 \mathrm{~g} \mathrm{~L}^{-1}\right)$ at 7 DAP; 3 - mycelial suspension $\left(5 \mathrm{~g} \mathrm{~L}^{-1}\right)$ at $14 \mathrm{DAP} ; 4$ - mycelial suspension $\left(5 \mathrm{~g} \mathrm{~L}^{-1}\right)$ at 21 DAP; 5 - mycelial suspension $\left(5 \mathrm{~g} \mathrm{~L}^{-1}\right)$ at 7, 14 and 21 DAP; 6 - mycelial mass extract $\left(1,040 \mu \mathrm{g} \mathrm{mL}^{-1}\right)$ at $7 \mathrm{DAP} ; 7$ - mycelial mass extract $\left(1,040 \mu \mathrm{g} \mathrm{mL}^{-1}\right)$ at $14 \mathrm{DAP} ; 8$ - mycelial mass extract $\left(1,040 \mu \mathrm{g} \mathrm{mL}^{-1}\right)$ at $21 \mathrm{DAP} ; 9$ - mycelial mass extract $\left(1,040 \mu \mathrm{g} \mathrm{mL}^{-1}\right)$ at 7,14 and $21 \mathrm{DAP} ; 10$ - control. The mycelial suspension and mycelial mass extract were added to the soil at $50 \mathrm{~mL} / 3 \mathrm{~kg}$ of soil.

For all the assays, analyses of variance and the Tukey test $(\mathrm{p}<0.05)$ were performed using the $\mathrm{R}$ software, version 3.0.1 (R Core Team 2019), and all the data from the greenhouse assays were transformed $(\sqrt{x}+0.5)$.

\section{RESULTS AND DISCUSSION}

The mycelial mass extract at $1,040 \mu \mathrm{g} \mathrm{mL}-1$ inhibited the colony area of C. miyabeanus, M. albescens and $S$. oryzae by 33, 12.5 and $51 \%$, respectively (Figures $2 \mathrm{~B}, 2 \mathrm{D}$ and $2 \mathrm{~F}$ ). The crude (120 and $\left.12 \mu \mathrm{g} \mathrm{mL}^{-1}\right)$ and lyophilized $\left(520 \mu \mathrm{g} \mathrm{mL}^{-1}\right)$ extracts inhibited C. miyabeanus by 29.40 and $29.49 \%$, respectively, and M. albescens by $26.5 \%$ (Figures 3A and 3F). Carvalho et al. (2015) showed that the crude extract $\left(700 \mu \mathrm{g} \mathrm{mL}^{-1}\right)$ is the only extract that inhibits the mycelial growth of $M$. oryzae by $75 \%$.

The mycelial mass extract was obtained in a few steps and 14 days (Figure 1A), while the lyophilized (Figure 1B), crude (Figure 1B) and mycelial (Figure 1C) extracts demanded a high number of stages and 30, 27 and 26 days, respectively (Figure 1). Therefore, among the tested extracts, the mycelial mass extract showed the best cost-benefit ratio, because it is faster to obtain, uses less solvent and needs minor amounts of PDA. All the extracts studied by mass spectrometry have sugar adducts and are the major interference by ion suppression on presence of saccharides adducts derivatives, but the new extract has minor interferences, because it has less amounts of PDA.

Côrtes et al. (2014) also demonstrated that the $S$. oryzae crude extract inhibits the $M$. oryzae mycelial growth by $79 \%$, and Dethoup et al. (2018) detected the inhibition of four rice pathogens (Alternaria padwickii, Bipolaris oryzae, Curvularia lunata and Fusarium moniliforme) using Talaromyces tratensis crude extract.

Therefore, a more sensitive and accurate test with the mycelial mass extract was performed to verify its potential for inhibiting the conidial germination and appressorium formation for the main rice pathogen (M. oryzae).

The tested concentrations of mycelial mass extract affected the germination and appressorium formation of $M$. oryzae at different times. The mycelial mass extract $\left(1,040 \mu \mathrm{g} \mathrm{mL}^{-1}\right)$ inhibited the $M$. oryzae conidial germination by 59.22 and $74.50 \%$ and the appressorium formation by 44.74 and $85.86 \%$, at 4 and $6 \mathrm{~h}$ after the contact, 


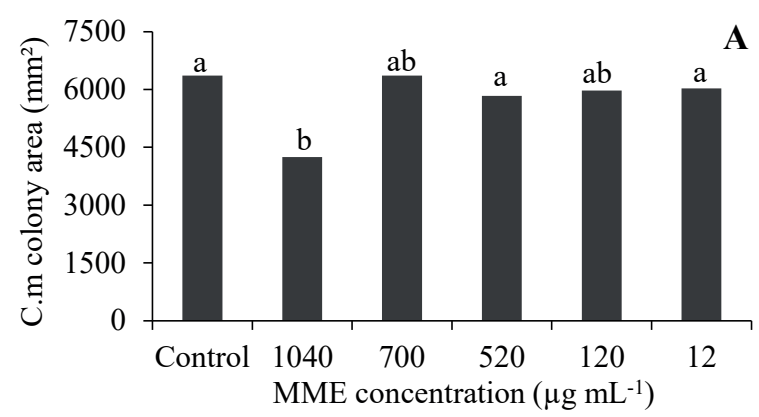

A 7500
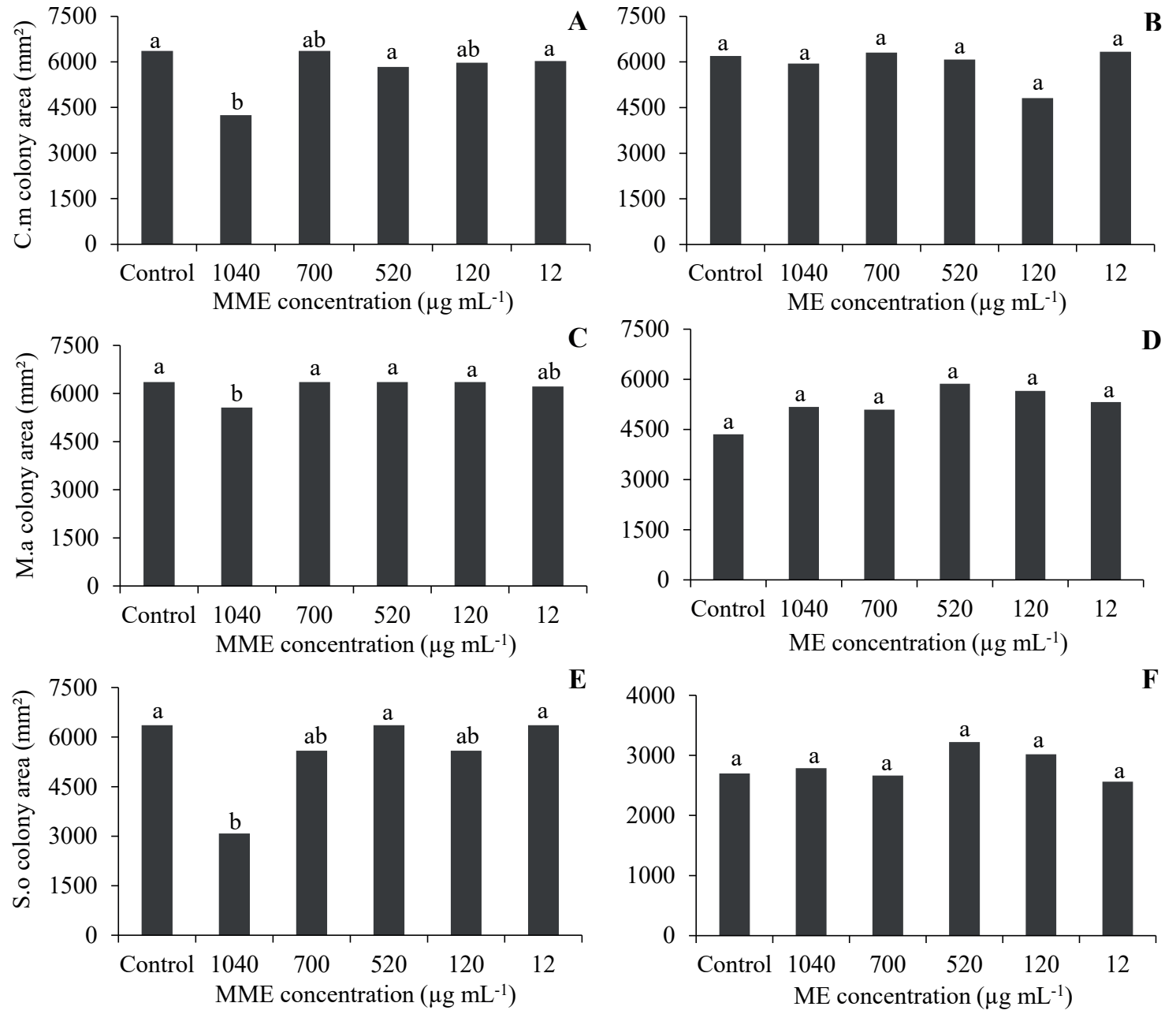

Figure 2. Inhibition of mycelial growth of rice pathogens by mycelial (ME) and mycelial mass (MME) extracts of W. circinata. C.m: Cochliobolus miyabeanus; M.a: Monographella albescens; S.o: Sarocladium oryzae. Means followed by the same letter were not significantly different from each other, according to the Tukey test $(\mathrm{p}<0.05)$.

respectively. Carvalho et al. (2015) reported that the crude, lyophilized and mycelial extracts inhibit the conidial germination at $24 \mathrm{~h}$ by up to $31 \%$, and that the crude extract inhibits the $M$. oryzae appressorium formation by $100 \%$ at 3, 6 and $24 \mathrm{~h}$ (Figure 4). Although Carvalho et al. (2015) detected up to $100 \%$ of inhibition for appressorium formation by the crude extract, the present study detected a higher conidial germination inhibition $(74.50 \%)$ in the first hours after the contact with the mycelial mass extract (4 and $6 \mathrm{~h}$ ), and the appressorium formation was reduced in the first hours after the contact with the mycelial mass extract. Therefore, the mycelial mass extract concentration of $1,040 \mu \mathrm{g} \mathrm{mL}^{-1}$ is the most recommended one, because its best effect occurred in the initial hours of contact with $M$. oryzae, interfering in the beginning of the pathogen cycle. Cortês et al.
(2014) also demonstrated that $S$. oryzae crude extract containing cerulenin inhibits the germination and appressorium formation of $M$. oryzae by $98 \%$ and $99 \%$, respectively, at $24 \mathrm{~h}$.

For the simultaneous application, in the first assay, the mycelial mass and crude extracts showed 0.13 and $0.59 \%$ of leaf blast severity and 2.13 and 3.18 of AUDPC, when compared to the control, which presented $18.86 \%$ of leaf blast severity and 27.83 of AUDPC (Figure 5).

In the second assay, the treatments containing the mycelial suspensions, crude extract and mycelial mass extract reduced the leaf blast severity, with values of 4.50, 5.22 and $5.24 \%$, respectively, when compared to the control (16.38\%) (Figure 6).

The third assay showed that the AUDPC and the leaf blast severity were reduced by the mycelial 

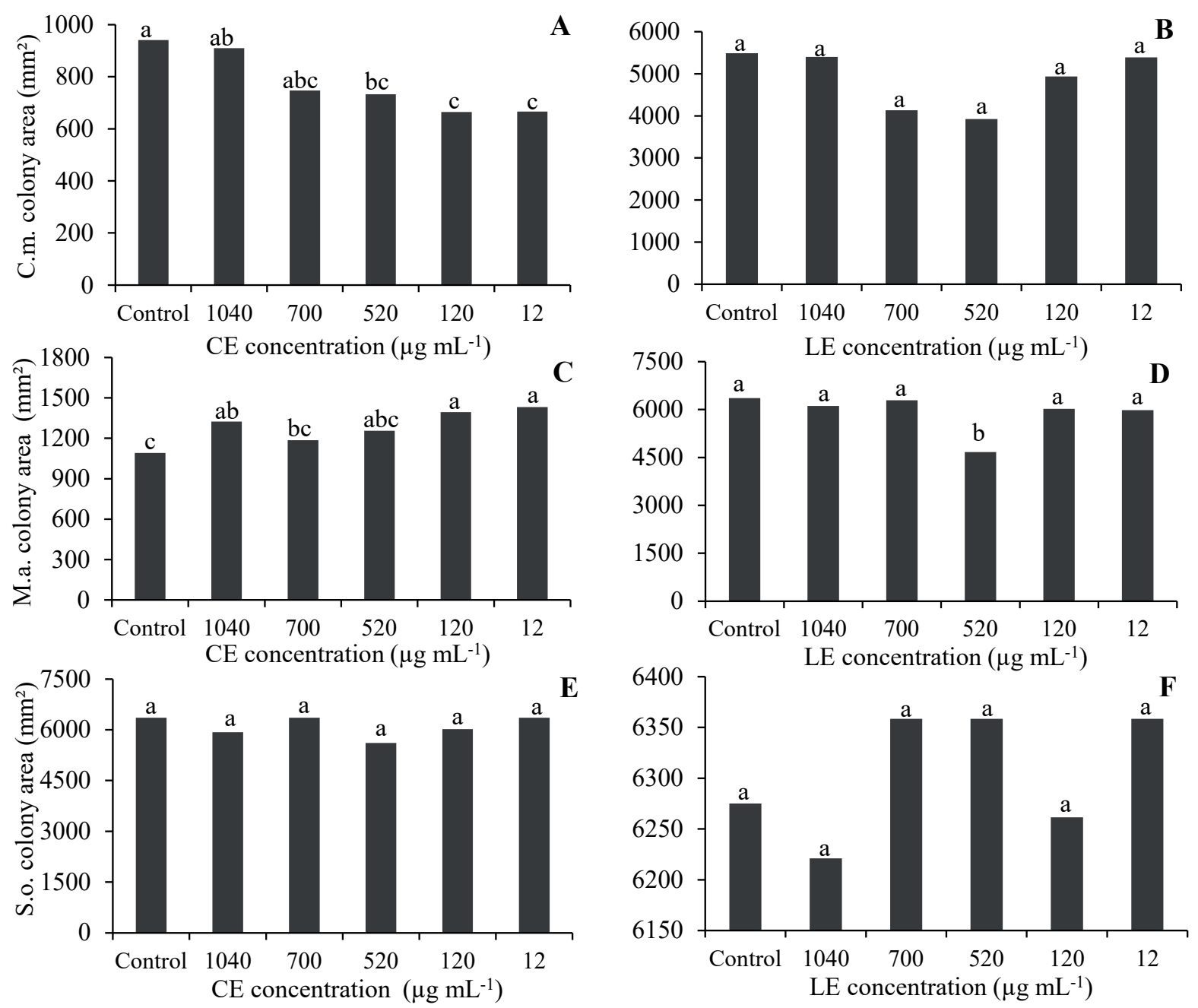

Figure 3. Inhibition of mycelial growth of rice pathogens by crude (CE) and lyophilized (LE) extracts of W. circinata. C.m: Cochliobolus miyabeanus, M.a: Monographella albescens; S.o: Sarocladium oryzae. Means followed by the same letter were not significantly different from each other, according to the Tukey test $(\mathrm{p}<0.05)$.
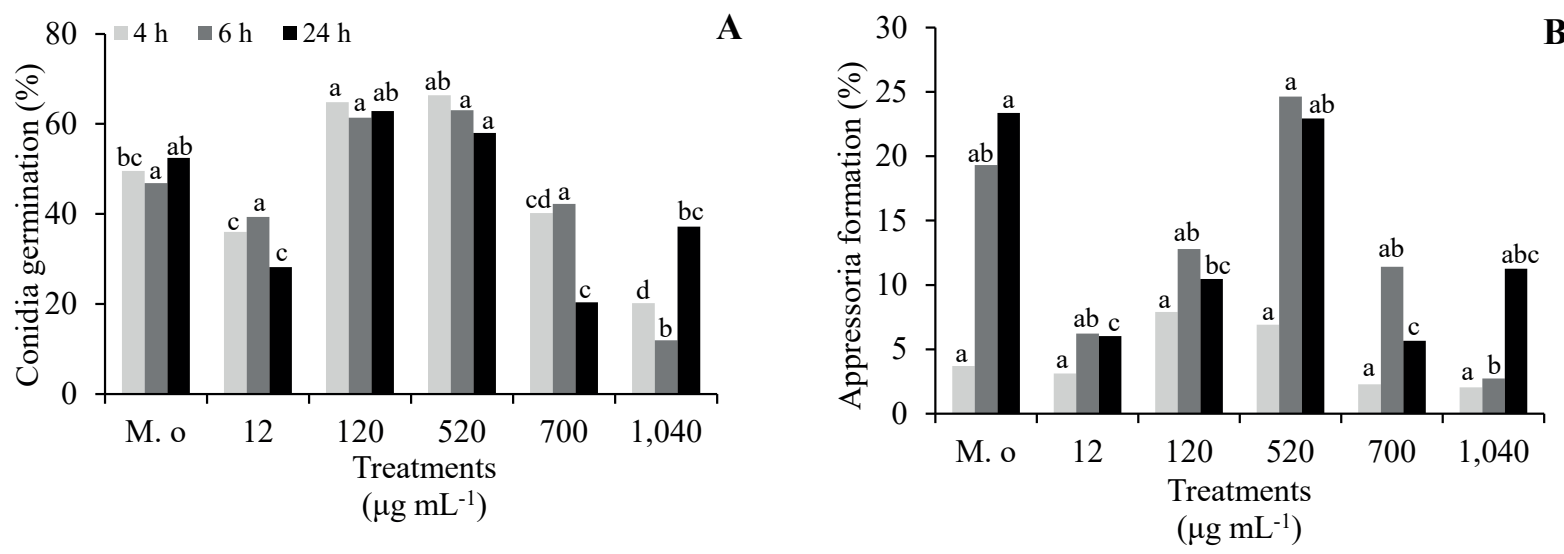

Figure 4. Effect of mycelial mass extract (MME) at 12, 120, 520, 700 and 1,040 $\mu \mathrm{g} \mathrm{mL}^{-1}$ against Magnaporthe oryzae (M.o) without mycelial mass extract (control). A) M. oryzae conidia germination; B) appressoria formation at 4, 6 and $24 \mathrm{~h}$ after the conidial deposition on the surface. Means followed by the same letter were not significantly different from each other, according to the Tukey test $(\mathrm{p}<0.05)$. 


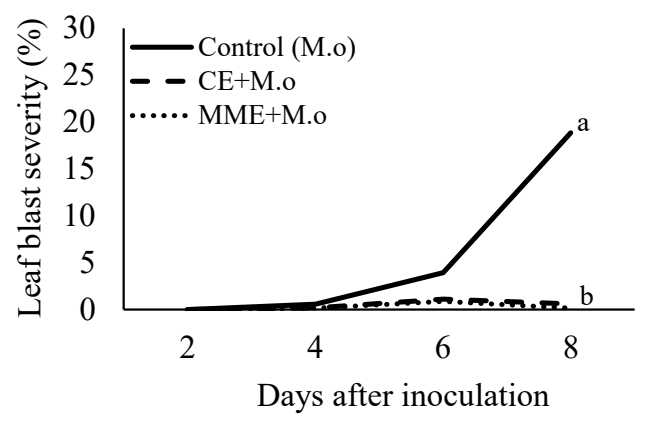

Figure 5. Leaf blast severity and area under the disease progress curve in rice plants treated with crude (CE) and mycelial mass (MME) extracts at $1,040 \mu \mathrm{g} \mathrm{mL}^{-1}$ and control inoculated only with Magnaporthe oryzae (M.o). Means followed by the same letter were not significantly different, according to the Tukey test $(\mathrm{p}<0.05)$.

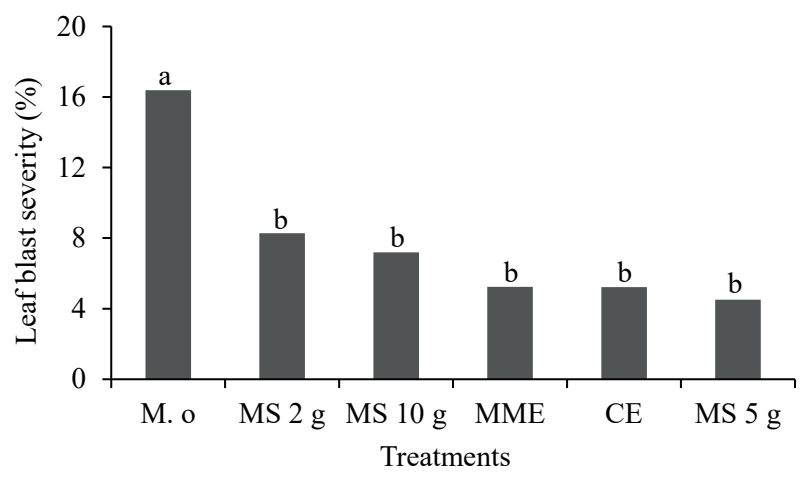

Figure 6. Leaf blast severity of rice plants treated with crude (CE) and mycelial mass (MME) extracts at $1,040 \mu \mathrm{g} \mathrm{mL}^{-1}$ and mycelial suspensions (MS) at 2, 5 and $10 \mathrm{~g} \mathrm{~L}^{-1}$, when compared with the control inoculated only with Magnaporthe oryzae (M.o). Means followed by the same letter were not significantly different, according to the Tukey test $(\mathrm{p}<0.05)$.

suspension $\left(5 \mathrm{~g} \mathrm{~L}^{-1} ; 5.58\right.$ and $\left.16.16 \%\right)$, crude extract $(1.87$ and $6.31 \%)$ and mycelial mass extract $(0.91$ and $3.72 \%)$, when compared to the control (16.71 and $40.4 \%$ ) (Figure 7). The treatments with $5 \mathrm{~g} \mathrm{~L}^{-1}$ of mycelial suspensions and mycelial mass extract suppressed the leaf blast by 72 and $68 \%$, respectively. When the effectiveness of $5 \mathrm{~g} \mathrm{~L}^{-1}$ of mycelial suspensions, crude extract and mycelial mass extract were compared, the AUDPC was reduced by 60,85 and $91 \%$, respectively. In a study by Carvalho et al. (2015), the crude extract reduced the AUDPC by $25 \%$, at eight days after the inoculation with M. oryzae, using mycelial suspensions. Dethoup et al. (2018) showed brown spot and dirty panicle reductions of 56.74 and $60 \%$ in rice, after treatment

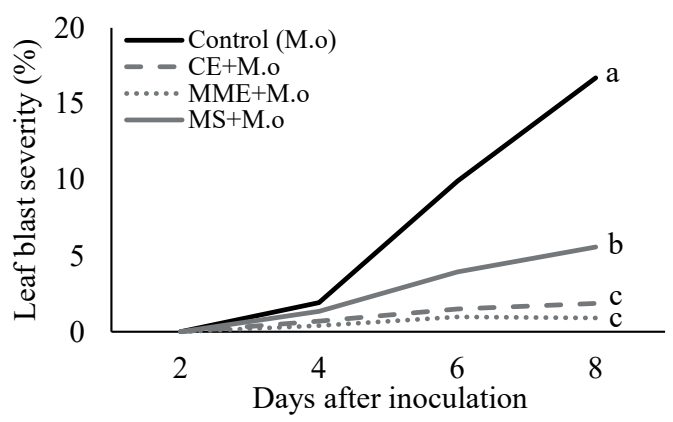

Figure 7. Leaf blast severity and area under the disease progress curve, in rice plants treated with mycelial suspension (MS) at $5 \mathrm{~g} \mathrm{~L}^{-1}$, crude (CE) and mycelial mass (MME) extracts at $1,040 \mu \mathrm{g} \mathrm{ml}^{-1}$, when compared with the control inoculated only with Magnaporthe oryzae (M.o). Means followed by the same letter were not significantly different, according to the Tukey test $(\mathrm{p}<0.05)$.

with crude extract and conidial suspension of T. tratensis, respectively.

The effect of the different extracts (crude and mycelial mass extracts) is probably due to the composition of the metabolites, that may act synergistically or not, cultivation of the bioagent and how to obtain it (El-Hossary et al. 2017, Dethoup et al. 2018).

For the previous application, all the treatments reduced the leaf blast severity, when compared to the control, except for the mycelial mass extract at 14 DAP. The treatments mycelial suspension at 14 DAP, mycelial mass extract and mycelial suspension at 7, 14 and 21 DAP, and mycelial mass extract at 21 DAP showed a lower leaf blast severity, with values of $2.95,2.23,2.22$ and $1.81 \%$, respectively, when compared to the control (30.6\%) (Figure 8).

Promising results have also been obtained with previous applications. The suppression of leaf blast by soil mixed with fungal discs reached $84 \%$, if compared to the control. For the treatments applied on the soil by drenching with mycelial suspension, the suppression percentages were $82 \%$ (7 DAP), $90 \%$ (14 DAP), $24 \%$ (21 DAP) and $93 \%$ (7, 14 and 21 DAP). The suppression percentages, when mycelial mass extract was applied on soil by drenching, were $62 \%$ (7 DAP), $94 \%$ (21 DAP) and $93 \%$ (7, 14 and 21 DAP). These findings indicate that $W$. circinata and its extracts may have more than one mechanism against rice blast, corroborating the results by $\mathrm{Xu}$ et al. (2016).

We hypothesized that the previous application of both the fungus and extracts on the soil was due 


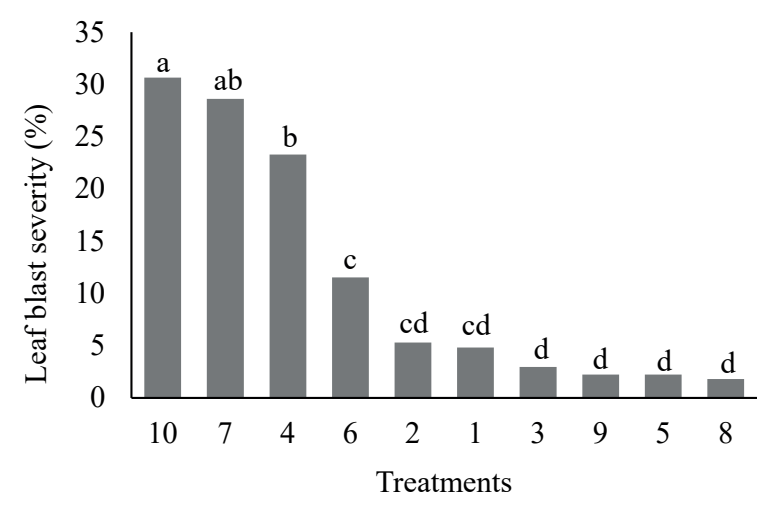

Figure 8. Leaf blast severity of rice plants treated with: 1 - soil (soil mixed with $5 \mathrm{~g} \mathrm{~kg}^{-1}$ of fungal disc before planting); 2 - mycelial suspension $\left(5 \mathrm{~g} \mathrm{~L}^{-1}\right)$ at 7 days after planting (DAP); 3 - mycelial suspension $\left(5 \mathrm{~g} \mathrm{~L}^{-1}\right)$ at $14 \mathrm{DAP}$; 4 - mycelial suspension $\left(5 \mathrm{~g} \mathrm{~L}^{-1}\right)$ at $21 \mathrm{DAP} ; 5$ - mycelial suspension $\left(5 \mathrm{~g} \mathrm{~L}^{-1}\right)$ at 7,14 , and 21 DAP; 6 - mycelial mass extract $\left(1,040 \mu \mathrm{g} \mathrm{mL}^{-1}\right)$ at $7 \mathrm{DAP} ; 7$ - mycelial mass extract $\left(1,040 \mu \mathrm{g} \mathrm{mL}^{-1}\right)$ at $14 \mathrm{DAP} ; 8$ - mycelial mass extract $\left(1,040 \mu \mathrm{g} \mathrm{mL}^{-1}\right)$ at $21 \mathrm{DAP} ; 9$ - mycelial mass extract $\left(1,040 \mu \mathrm{g} \mathrm{mL}^{-1}\right)$ at 7,14 and $21 \mathrm{DAP}$; 10 - control (inoculated only with Magnaporthe oryzae). Means followed by the same letter were not significantly different, according to the Tukey test $(\mathrm{p}<0.05)$.

to a resistance inducer, because the pathogen was presented on the leaf surface and $W$. circinata is a root inhabitant. The simultaneous leaf application, however, showed an antibiosis effect, due to the action of toxic compounds directly on the pathogen. Similarly to the present study, Chaibub et al. (2019) demonstrated that the leaf blast severity reaches $83.78 \%$, when Cladosporium cladosporioides is administered at $24 \mathrm{~h}$ or $48 \mathrm{~h}$ before $M$. oryzae.

The $W$. circinata mycorrhizal fungus is a promising option for formulations of bioproducts, as it is a non-mandatory symbiotic, what facilitates its large-scale production. Besides, in a previous study, $W$. circinata increased the rate of symbiotic germination in vitro by $81 \%$ (Carvalho et al. 2015). This effect is due to the increase in water and nutrient uptake (Rasmussen \& Rasmussen 2009), which act as antagonists to plant pathogens (Mosquera-Espinosa et al. 2013, Carvalho et al. 2015).

Therefore, this study of the $W$. circinata effects and its extracts and metabolites against important rice pathogens will allow the inclusion of a single biocontrol agent adapted to the Cerrado (Brazilian Savanna) conditions in the rice disease control management.

\section{CONCLUSION}

The new mycelial mass extract showed to be the most efficient one for inhibiting the mycelial growth of rice pathogens and suppressing rice blast, when compared to the other extracts; therefore, it has a potential for use in rice fields, reducing the use of fungicides and promoting a more sustainable agriculture.

\section{REFERENCES}

AGROFIT. Sistemas de agrotóxicos fitossanitários. 2021. Available at: http://agrofit.agricultura.gov.br/agrofit_cons/ principal_agrofit_cons. Access on: 03 Jan. 2021.

ALIFERIS, K. A.; CHRYSAYI-TOKOUSBALIDES, M. Metabolomics in pesticide research and development: review and future perspectives. Metabolomics, v. 7, n. 1, p. 35-53, 2011.

BOZDOGAN, A. M. Assessment of total risk on nontarget organisms in fungicide application for agricultural sustainability. Sustainability, v. 6, n. 2, p. 1046-1058, 2014.

CARVALHO, J. C. B.; SOUSA, K. C. I.; BRITO, D. C.; CHAIBUB, A. A.; LUZINI, A. P.; CÔRTES, M. V. C. B.; FILIPPI, M. C. C.; KATO, L.; VAZ, B. G.; COSTA, H. B.; ROMÃO, W.; ARAÚJO, L. G. Biocontrol potential of Waitea circinata, an orchid mycorrhizal fungus, against the rice blast fungus. Tropical Plant Pathology, v. 40, n. 3, p. 151-159, 2015.

CHAIBUB, A. A.; SOUSA, T. P.; ARAÚJO, L. G.; FILIPPI, M. C. C. Cladosporium cladosporioides $\mathrm{C} 24 \mathrm{G}$ modulates gene expression and enzymatic activity during leaf blast suppression in rice plants. Journal of Plant Growth Regulation, v. 39, n. 3, p. 1140-1152, 2019.

CHAIBUB, A. A.; SOUSA, T. P.; OLIVEIRA, M. I. S.; ARRIEL-ELIAS, M. T.; ARAÚJO, L. G.; FILIPPI, M. C. C. Efficacy of Cladosporium cladosporioides $\mathrm{C} 24 \mathrm{G}$ as a multifunctional agent in upland rice in agroecological systems. International Journal of Plant Production, v. 14, n. 3, p. $463-474,2020$.

CÔRTES, M. V. C. B.; SILVA-LOBO, V. L.; FILIPPI, M. C. C.; LIMA, D. C. S.; PRABHU, A. S. Potential for using crude extract of Sarocladium oryzae for suppression of rice blast. Tropical Plant Pathology, v. 39, n. 1, p. 28-34, 2014

DETHOUP, T.; KAEWSALONG, N.; SONGKUMORN, P.; JANTASOR, A. Potential application of a marinederived fungus, Talaromyces tratensis KUFA 0091 against rice diseases. Biological Control, v. 119, n. 1, p. 1-6, 2018. 
EL-HOSSARY, E. M.; CHENG, C.; HAMED, M. M.; HAMED, A. N. E.; OHLSEN, K.; HENTSCHEL, U.; ABDELMOHSEN, U. R. Antifungal potential of marine natural products. European Journal of Medicinal Chemistry, v. 126, n. 1, p. 631-651, 2017.

FILIPPI, M. C. C.; PRABHU, A. S. Phenotypic virulence analysis of Pyricularia grisea isolates from Brazilian upland rice cultivars. Pesquisa Agropecuária Brasileira, v. 36, n. 1, p. 27-35, 2001.

FISHER, M. C.; HENK, D. A.; BRIGGS, C. J.; BROWNSTEIN, J. S.; MADOFF, L. C.; MCCRAW, S. L.; GURR, S. J. Emerging fungal threats to animal, plant and ecosystem health. Nature, v. 484, n. 7393, p. 186194, 2012.

INSTITUTO BRASILEIRO DO MEIO AMBIENTE E DOS RECURSOS NATURAIS RENOVÁVEIS (Ibama). Boletins anuais de produção, importação, exportação e vendas de agrotóxicos no Brasil. 2018. Available at: http://ibama.gov.br/agrotoxicos/relatorios-decomercializacao-de-agrotoxicos\#boletinsanuais. Access on: 05 June 2020.

LAHA, G. S.; SINGH, R.; LADHALAKSHMI, D.; SUNDER, S.; SRINIVAS, M.; PRASAD, C. S.; DAGAR, V.; RAVINDRA, B. Importance and management of rice diseases: a global perspective. In: CHAUHAN, B. S.; JABRAN, K.; MAHAJAN, G. (ed.). Rice production worldwide. Cham: Springer, 2017. p. 303-360.

MOSQUERA-ESPINOSA, A. T.; BAYMAN, P.; PRADO, G. A.; GOMEZ-CARABALI, A.; OTERO, J. T. The double life of Ceratobasidium: orchid mycorrhizal fungi and their potential for biocontrol of Rhizoctonia solani sheath blight of rice. Mycologia, v. 105, n. 1, p. 141-150, 2013.

NARAYANASAMY, P. Mechanisms of action of bacterial biological control agents. In: NARAYANASAMY, P. Biological management of diseases of crops: progress in biological control. Dordrecht: Springer, 2013. p. 295429.

NASCIMENTO, F. A.; ALVES, A. A.; NUNES, H. F.; MIZIARA, F.; PARISE, M. R.; SILVA, D. M. Cultivated areas and rural workers' behavior are responsible for the increase in agricultural intoxications in Brazil? Are these factors associated? Environmental Science and Pollution Research, v. 27, n. 30, p. 38064-38071, 2020.

NOTTEGHEM, J. L. Cooperative experiment on horizontal resistance to rice blast. In: INTERNATIONAL RICE RESEARCH INSTITUTE. Blast and upland rice: report and recommendations from the meeting for international collaboration in upland rice improvement. Los Baños: International Rice Research Institute, 1981. p. 43-51.
OLIVEIRA, M. I. S.; CHAIBUB, A. A.; SOUSA, T. P.; CORTÊS, M. V. C. B.; SOUZA, A. C. A.; CONCEIÇÃO, E. C.; FILIPPI, M. C. C. Formulations of Pseudomonas fluorescens and Burkholderia pyrrocinia control rice blast of upland rice cultivated under no-tillage system. Biological Control, v. 144, e104153, 2020.

OU, S. H. Rice diseases. Kew: Commonwealth Mycological Institute, 1985.

PRABHU, A. S.; FILIPPI, M. C. C.; SILVA, G. B.; SILVALOBO, V. L.; MORAIS, O. P. An unprecedented outbreak of rice blast on a newly released cultivar BRS Colosso in Brazil. In: WANG, G. L.; VALENT, B. (ed.). Advances in genetics, genomics and control of rice blast. Cham: Springer, 2009. p. 257-267.

R CORE TEAM. $R$ : a language and environment for statistical computing. Version 3.0.1. Vienna: R Foundation for Statistical Computing, 2019.

RAO, K. Sheath rot disease of rice. New Delhi: Daya Publishing House, 1996.

RASMUSSEN, H. N.; RASMUSSEN, F. N. Orchid mycorrhiza: implications of a mycophagous life style. Oikos, v. 118, n. 3, p. 334-345, 2009.

SHANER, G.; FINNEY, R. F. The effects of nitrogen fertilization on the expression slow-mildewing in Knox wheat. Phytopathology, v. 67, n. 8, p. 1051-1056, 1977.

SOUSA, K. C. I.; ARAÚJO, L. G.; SILVA, C. S.; CARVAlHO, J. C. B.; SIBOV, S. T.; GONÇALVES, L. A.; PEREIRA, M. C.; GONÇALVES, F. J.; FILIPPI, M. C. C. Seed germination and development of orchid seedlings (Cyrtopodium saintlegerianum) with fungi. Rodriguésia, v. 70, e02302016, 2019.

SUNDER, S.; SINGH, R.; AGARWAL, R. Brown spot of rice: an overview. Indian Phytopathology, v. 67, n. 3, p. 201-215, 2014.

SYNYTSYA, A.; MONKAI, J.; BLEHA, R.; MACURKOVA,A.; RUML, T.;AHN, J.; CHUKEATIROTE, E. Antimicrobial activity of crude extracts prepared from fungal mycelia. Asian Pacific Journal of Tropical Biomedicine, v. 7, n. 3, p. 257-261, 2017.

XU, T.; LI, Y.; ZENG, X.; YANG, X.; YANG, Y.; YUAN, S.; HU, X.; ZENG, J.; WANG, Z.; LIU, Q.; LIU, Y.; LIAO, H.; TONG, C.; LIU, X.; ZHU, Y. Isolation and evaluation of endophytic Streptomyces endus OsiSh-2 with potential application for biocontrol of rice blast disease. Journal of the Science of Food and Agriculture, v. 97, n. 4, p. 11491157, 2017.

YEH, C. M.; CHUNG, K.; LIANG, C. K.; TSAI, W. C. New insights into the symbiotic relationship between orchids and fungi. Applied Science, v. 9, e585, 2019. 